\title{
Changes in the Shelf Life Parameters of Dietary Supplement During Storage
}

\author{
KANIKA PAWAR $^{1^{\star}}$ and D K THOMPKINSON ${ }^{2}$ \\ ${ }^{1 " D e p a r t m e n t ~ o f ~ P r o c e s s i n g ~ a n d ~ F o o d ~ E n g i n e e r i n g, ~ C o l l e g e ~ o f ~ A g r i c u l t u r a l ~}$ \\ Engineering and Technology, Chaudhary Charan Singh Haryana \\ Agricultural University, Hisar, Haryana, India, 125004 \\ ${ }^{2}$ Warner School of Food and Dairy Technology, Sam Higginbottom Institute of \\ Agriculture, Technology \& Sciences, Allahabad, Uttar Pradesh, 211007, India \\ Corresponding author E-mail: kanikapawar@gmail.com \\ http://dx.doi.org/10.12944/CRNFSJ.5.1.03
}

(Received: January 22, 2017; Accepted: April 10, 2017)

\begin{abstract}
A dietary supplement containing multifunctional ingredient sources was formulated and optimized for management of diabetes. The formulated dietary supplement comprised of milk fat and groundnut oil (90:10), whey protein concentrate, skim milk powder and sodium caseinate (50:25:25) and resistant starch and maltodextrin (70:30). The feasibility of the formulated dietary supplement in terms of physico-chemical, microbiological and sensory attributes was evaluated during storage period. The formulated supplement was found to have 4.37, 15.93, 10.15, 3.39 and 66.15 percent moisture, protein, fat, ash and carbohydrate respectively. It was observed that there was slight increase in moisture, free fatty acid, thiobarbituric acid and insolubility index while a decrease in dispersibility and sensory attributes (color and appearance, flavor, overall acceptability) during the storage period. However, the dietary supplement stored at room temperature indicated non-significant changes in all physico-chemical, microbiological and sensory parameters throughout the storage period of 180 days. Thus, dietary supplement prepared had better acceptability for a period of six months.
\end{abstract}

Keywords: Dietary Supplement, physico-chemical, sensory, storage studies.

\section{INTRODUCTION}

Diabetes is a metabolic disorder characterized by hyperglycemia. Globally, in 2013 382 million people were diabetic and by the year 2035 this number is expected to rise to 592 million while in India, 65.1 million are diabetic and by 2035 this number is expected to an increase of 592 million as reported by International Diabetes Federation $(\text { IDF })^{14}$. It is also accompanied by several health implications viz. cardiovascular diseases, obesity, hypertension, cancer, depression and eating disorders. The concept of dietary supplement is fast expanding, and has potential benefits to promote health and reduce the risk of chronic diseases and have hence been given much attention. Functional foods-based diet has been hypothesized as a novel and comprehensive dietary approach for management of diabetes and prevention of longterm complications ${ }^{27}$. Therefore an effective way for management of individuals suffering with diabetes could be through modifications in the diet and by addition of multiple functional ingredients.

The various multifunctional ingredient in the dietary formulation comprises of groundnut oil as a source of monounsaturated fatty acids, whey protein concentrate and sodium caseinate as source for essential amino acids along with the longer gastric emptying time (for sustainable protein release) and the insulinotropic effects shown by the protein. The carbohydrate part comprised of resistant wheat 
starch along with maltodextrin. Resistant wheat starch is being added due to the slow digestion, lowered insulin responses and controlled glucose release being imparted for diabetic personnel while minimum amount of maltodextrin was being kept to prevent the hypoglycemic effect in initial hours of digestion. The ratios in which the different functional ingredients added in the dietary supplement comprised of milk fat and groundnut oil (90:10), whey protein concentrate, skim milk powder and sodium caseinate (50:25:25) and resistant wheat starch and maltodextrin (70:30). Therefore, the aim of this study was to formulate a dietary supplement and to evaluate the shelf life parameters i.e. physicochemical, microbiological and sensory feasibility during storage.

\section{MATERIAL and METHODS}

Fibersym ${ }^{\circledR} \mathrm{RW}$ resistant wheat starch was procured from MGP, Ingredients Inc. Kansas (U.S.A) while the Maltodextrin (DE- 22-25) was supplied from M/s Rai agro Industries Ltd., Sangrur, Punjab. Whey protein concentrate (WPC-70) was purchased from Modern Dairy Private Ltd., Karnal (Haryana). Sodium Caseinate was purchased from Avani Food Products, Mehsana (Gujarat). Ground nut oil (Amrit banaspati Co. Ltd, Rajpura) was obtained from the local market. Partially hydrolyzed guar gum was used as the source of soluble dietary fiber under the brand name Sunfiber ${ }^{\circledR}$ was purchased from Taiyo Lucid Pvt. Ltd., Mumbai. Cocoa powder added as a flavoring agent from Cadbury India Limited, Mumbai was purchased from local market. Splenda ${ }^{\circledR}$ Sucralose as a non-caloric sweetener was procured from Tate and Lyle, Mumbai. All the chemicals used in the analysis were of analytical grade and procured from Central Drug house, New Delhi.

A dietary supplement was formulated in accordance to the nutritional requirements of $1800 \mathrm{Kcal} /$ day as recommended by Indian Council of Medical Research ${ }^{18}$ for diabetic adult. The fat, protein and carbohydrate components were selected to supply $20-25$ percent; $10-15$ percent and 55-65 percent respectively of the total calorie in the dietary supplement. To optimize the various ingredients, Response Surface Methodology (RSM) based on central composite rotatable design (CCRD), using three independent variables (ingredient sources) and five responses comprising of sensory and physicochemical parameters were used for computation ${ }^{31}$. The dietary supplement comprising of milk fat and groundnut oil (90:10) as fat source, whey protein concentrate, skim milk powder and sodium caseinate (50:25:25) as protein source while resistant wheat starch and maltodextrin (70:30) as carbohydrate source were used to prepare the formulation.

\section{Preparation of dietary supplement}

Predetermined amounts of milk fat (desi ghee) and groundnut oil were taken and heated to $40^{\circ} \mathrm{C}$ and mixed well for preparation of the fat blend. The selected fat blend along with maltodextrin as source of carbohydrate; whey protein concentrate and sodium caseinate as a source of high quality protein (with functionality of fat encapsulators) along with partially hydrolyzed guar gum (PHGG) as a source of soluble dietary fibre were mixed with calculated amount of skim milk. The contents were mixed well at $60-70^{\circ} \mathrm{C}$. The mixture was then homogenized at 2000 and 500 psi in a double stage homogenizer followed by spray drying at an inlet temperature of $200^{\circ} \mathrm{C}$ and outlet temperature of $90^{\circ} \mathrm{C}$ (Fig. 1). The spray-dried product was allowed to cool to room temperature. A calculated amount of resistant wheat starch; sweetener and cocoa powder as flavouring agent were dry blended to the spray dried product. The dried dietary supplement was packed in laminated pouches, heat sealed and stored at room temperature $\left(32-38^{\circ} \mathrm{C}\right)$ for a period of six months and tested periodically.

\section{Physico-chemical Analysis}

Dispersibility of the supplement was determined using method of $\mathrm{ADMI}^{1}$, and insolubility index was determined using IS: SP: 18 (Part XI) ${ }^{19}$ methods. Moisture and ash were determined using methods given in $\mathrm{AOAC}^{2}$. Protein and Fat were determined by IS: SP: 18 (Part XI) ${ }^{19}$. Carbohydrate was calculated by difference. Free fat was calculated by the method delineated by Hall and Hedrick ${ }^{16}$. Thiobarbituric acid (TBA) value was measured as per the method of Strange et $\mathrm{al}^{35}$ while the Free Fatty Acid content of dietary supplement samples was analyzed as per the method of Deeth and FitzGerald $^{11}$ with modifications. The preparation and maintenance of microbiological media used during the entire investigation was done following the method suggested by Marshall ${ }^{25}$. All enumeration 
was done using the pour plate method described by Haughty et al. ${ }^{17}$.

\section{Sensory Evaluation}

The formulated dietary supplement was subjected to sensory evaluation using 9 point hedonic scale ${ }^{5}$, by a panel of 10 semi trained panelists drawn from faculty of dairy technology division, National Dairy Research Institute, Karnal, Haryana, India.

\section{Statistical Analysis}

All data's were computed with the software application programmers (Microsoft Excel 2007). The results of all the studies were expressed as mean \pm standard error of mean. Significance was tested by employing analysis of variance (ANOVA) and comparison between means was made by critical difference (C.D) value.

\section{Results and Discussion}

\section{Optimized Dietary Supplement}

The optimization of dietary supplement was done using RSM in which the independent variables consisted of fat which ranged from $10-14 \mathrm{~g}$, carbohydrate $58-62 \mathrm{~g}$ while the protein ranged from 27-31g. Based on optimization, optimum levels of ingredients combinations recommended with 93 percent desirability was obtained. The optimum formulation consisted of $10.00 \mathrm{~g}$ fat, $27.20 \mathrm{~g}$ protein and $62.00 \mathrm{~g}$ carbohydrate. The dietary supplement

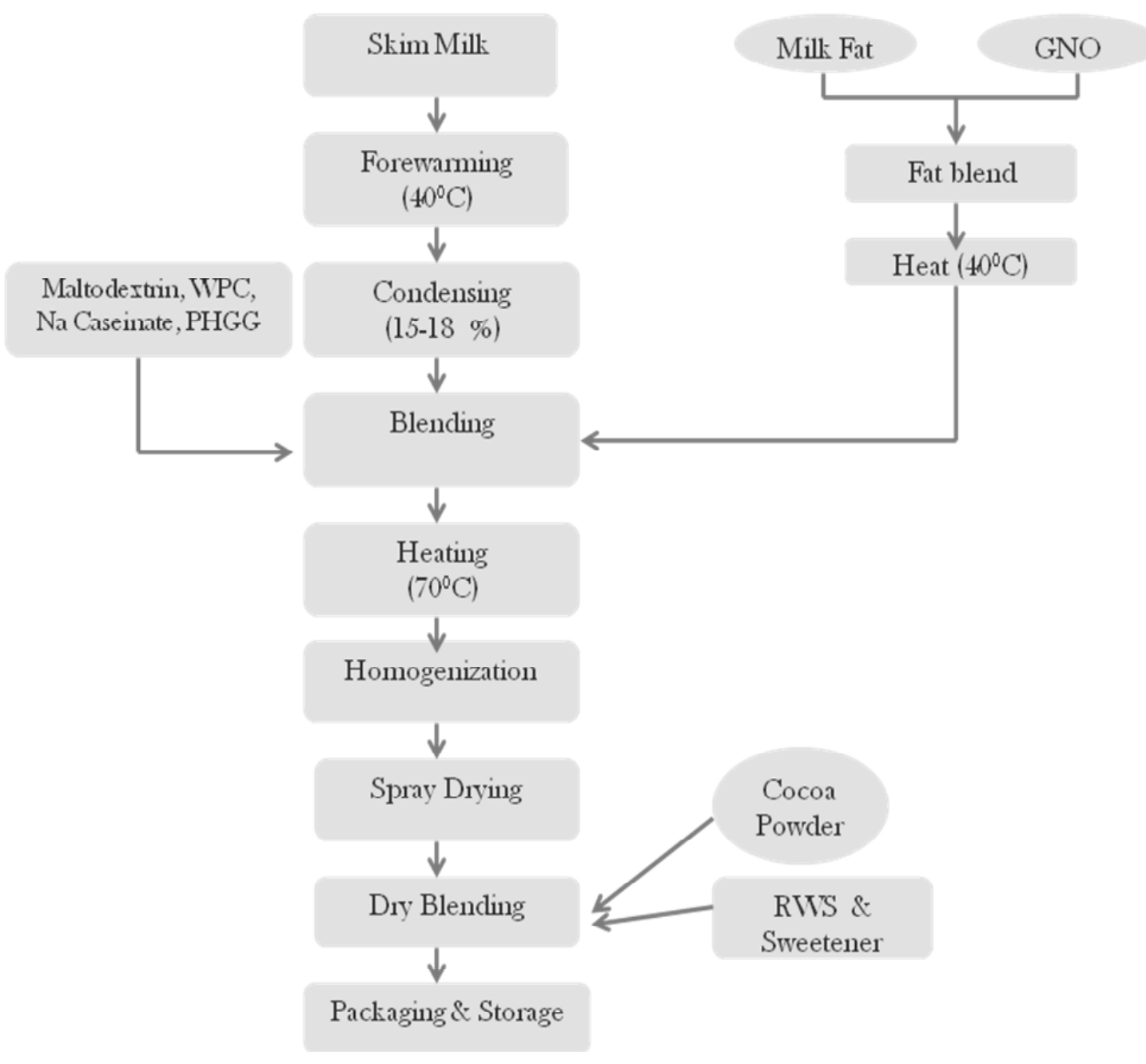

Fig. 1: Schematic for formulation of dietary supplement 
comprising of milk fat and groundnut oil (90:10) as fat source, whey protein concentrate, skim milk powder and sodium caseinate (50:25:25) as protein source while resistant wheat starch and maltodextrin (70:30) as carbohydrate source were used to prepare the formulation.

The optimized dietary supplement thus prepared was analyzed for proximate composition and found to have 4.37 percent moisture, 15.93 percent protein, 10.15 percent fat, 3.39 percent ash and 66.15 percent carbohydrate as shown in table 1 (a). Also the dietary supplement supplied a total of $417.67 \mathrm{kcal}$ per $100 \mathrm{~g}$ of the product. Moreover percent energy contributed by fat, protein and carbohydrate in an optimized dietary supplement was found to be $21.9,14.8$, and 63.4 percent respectively, which was well within the range specified by the ICMR for diabetic adult. While among the physico-chemical characteristics, it was found to have 7.02 percent, 80.90 percent, $0.69 \mathrm{ml}, 9.75 \mathrm{cp}$ respectively for free

Table 1(a): Proximate composition of optimized dietary supplement

\begin{tabular}{lcc}
\hline $\begin{array}{l}\text { Constituents } \\
\text { (Percent) }\end{array}$ & Values & $\begin{array}{c}\text { Energy } \\
\text { Contribution* }\end{array}$ \\
\hline Moisture content & $4.37 \pm 0.03$ & - \\
Fat & $10.15 \pm 0.26$ & $21.9 \%$ \\
Protein & $15.93 \pm 0.04$ & $14.8 \%$ \\
Ash & $3.39 \pm 0.01$ & - \\
Carbohydrate & $66.15 \pm 0.31$ & $63.4 \%$ \\
\hline
\end{tabular}

Figures are the average \pm standard error of three replications ${ }^{*}$ percent of total calorie requirement

Table 1(b): Physico-chemical characteristics of optimized dietary supplement

\begin{tabular}{lc}
\hline Parameters & Values \\
\hline Free Fat (\%) & $7.02 \pm 0.03$ \\
Dispersibility (\%) & $80.90 \pm 0.26$ \\
Insolubility index (ml) & $0.69 \pm 0.01$ \\
Viscosity (cp) & $9.75 \pm 0.26$ \\
Figures are the average \pm standard error of three \\
replications
\end{tabular}

fat, dispersibility and insolubility index, viscosity (Table 1(b)).

\section{Storage Studies}

The formulated dietary supplement was stored at room temperature for a period of 180 days and monitored for physico-chemical, microbiological and sensory changes at regular interval. The results are presented in table 2 and 3.

\section{Physico-chemical changes in the dietary supplement during storage Change in moisture}

Moisture content of dried product is an important parameter that invariably affects shelf life. Higher moisture content results in high water activity that supports microbial growth leading to lower shelf life. The results pertaining to changes in the moisture content of dietary supplement during storage at room temperature are given in Table 2. It may be observed, from the table 2, that there was a consistent increase in the moisture content throughout the storage period of 180 days and the values ranged from 3.80 percent to 5.85 percent. A non significant $(p>0.01)$ increase in moisture percent was observed during the initial 30 days followed by a significant $(p \leq 0.01)$ increase on the $60^{\text {th }}$ day of storage. However, a significant $(p>0.01)$ increase in the moisture was observed between 60,90 and 120 days of storage. While there was noticed a non significant $(p>0.01)$ increase between 120 and 180 days of storage period. Thus, the rise in moisture level was significantly affected $(p \leq 0.01)$ by the period of storage. However the change in moisture during the storage period did not affect the sensory quality of the dietary supplement as is evident from the non-significant changes in the sensory scores presented in Table 3. The moisture content is an important factor in the stability of the food product. As the moisture content increase during storage, it adversely influences the powder properties. The increase in the moisture content of dietary supplement during progressive storage might have been due to the hygroscopic nature of the ingredients used in the formulation and packaging of the product leading to higher initial moisture content of the formulation. Arora, ${ }^{4}$ found an increase in the moisture content from 3.20 to 3.78 percent after the 3 month of storage of instant dalia mix powder. Fitzpatrick et $\mathrm{al}^{12}$ found an increase in moisture content of dairy powders leading to 
decrease in their flowability. Cristina et al ${ }^{10}$. observed moisture content variations in the infant formula during 18 month storage period. Similarly Bunkar et $\mathrm{al}^{7}$. also reported an increase in moisture content of pearl millet kheer mix powder during the storage period. The observations recorded in the present investigation are in consistent with several previous reports. From the results it may be concluded that the dietary formulation exhibited an increase in the moisture percent during the storage period. However the increase in moisture was within the permissible limits, also it did not affect the sensory and physicochemical properties of the formulation.

\section{Change in dispersibility}

Dispersibility is the dispersion of agglomerates with little stirring. It describes the ease with which the powder may be distributed as single particles over the surface and throughout the bulk of the reconstituting water. Very dispersible powders typically exhibit good wettability and are agglomerated, with the absence of fine particles. The results with respect to change in dispersibility of dietary supplement are presented in Table 2. It was observed that dispersibility decreased as the period of storage progressed. The dispersibility of the dietary supplement decreased from 85.12 to 82.64 percent during 180 days of storage. However, statistical analysis (CD) indicates that the changes observed with respect to dispersibility of dietary supplement were non-significant $(p>0.01)$ change was during the storage period of 180 days. The decrease in the dispersibility values during storage could have been due to the increase in moisture content and free fat levels leading to low wettability ${ }^{33}$.

The changes in protein structure due to protein-protein interaction during storage could also be responsible for the loss of dispersibility ${ }^{26}$. The dispersibility of instant kheer mix powder was 75.38 percent which was decreased to 66.52 percent during a storage period at $30^{\circ} \mathrm{C}$ as observed by $\mathrm{Jha}^{21}$. Scheidegger et $\mathrm{al}^{32}$. found a significant decrease in dispersibility of commercially processed spray-dried milk powders during nine months of storage period. Bouvier et al. ${ }^{6}$ also observed a low dispersibility value in case of milk protein concentrate powders. From the results it can be concluded that the dispersibility of the dietary formulation decreases during the storage period. As the dispersibility of the spray

Table 2: Changes in the physico-chemical and microbiological attributes of dietary supplement during storage

\begin{tabular}{|c|c|c|c|c|c|c|c|c|}
\hline \multirow[t]{2}{*}{ Attributes } & \multirow[b]{2}{*}{0} & \multirow[b]{2}{*}{30} & \multicolumn{4}{|c|}{$\begin{array}{l}\text { Storage Period } \\
\text { (Days) }\end{array}$} & \multirow[b]{2}{*}{180} & \multirow[b]{2}{*}{$\mathrm{CD}_{0.05}$} \\
\hline & & & 45 & 60 & 90 & 120 & & \\
\hline Moisture (\%) & $\begin{array}{c}3.80^{\mathrm{a}} \pm \\
0.27\end{array}$ & $\begin{array}{c}3.94^{\mathrm{a}} \pm \\
0.03\end{array}$ & $\begin{array}{c}4.16^{\mathrm{a}} \pm \\
0.03\end{array}$ & $\begin{array}{c}4.45^{\mathrm{b}} \pm \\
0.04\end{array}$ & $\begin{array}{c}4.97^{c} \pm \\
0.04\end{array}$ & $\begin{array}{c}5.67^{d} \pm \\
0.10\end{array}$ & $\begin{array}{c}5.85^{\mathrm{d}} \pm \\
0.03\end{array}$ & 0.50 \\
\hline Dispersibility (\%) & $\begin{array}{c}85.12 \pm \\
0.30\end{array}$ & $\begin{array}{c}84.20 \pm \\
0.21\end{array}$ & $\begin{array}{c}83.84 \pm \\
0.87\end{array}$ & $\begin{array}{c}83.75 \pm \\
0.73\end{array}$ & $\begin{array}{c}83.56 \pm \\
0.02\end{array}$ & $\begin{array}{c}83.04 \pm \\
0.47\end{array}$ & $\begin{array}{c}82.64 \pm \\
0.03\end{array}$ & $1.91^{\mathrm{ns}}$ \\
\hline $\begin{array}{l}\text { Insolubility } \\
\text { Index (ml) }\end{array}$ & $\begin{array}{c}0.65 \pm \\
0.01\end{array}$ & $\begin{array}{c}0.65 \pm \\
0.01\end{array}$ & $\begin{array}{c}0.66 \pm \\
0.01\end{array}$ & $\begin{array}{c}0.66 \pm \\
0.01\end{array}$ & $\begin{array}{c}0.66 \pm \\
0.02\end{array}$ & $\begin{array}{c}0.67 \pm 0.02 \\
0.02\end{array}$ & $\begin{array}{c}0.68 \pm \\
0.01\end{array}$ & $0.035^{\mathrm{ns}}$ \\
\hline FFA $(\mu e q / g)$ & $\begin{array}{c}2.87 \pm \\
0.03\end{array}$ & $\begin{array}{c}3.04 \pm \\
0.12\end{array}$ & $\begin{array}{c}3.21 \pm \\
0.02\end{array}$ & $\begin{array}{c}3.31 \pm \\
0.10\end{array}$ & $\begin{array}{c}3.51 \pm \\
0.38\end{array}$ & $\begin{array}{c}3.66 \pm \\
0.17\end{array}$ & $\begin{array}{c}3.80 \pm \\
0.01\end{array}$ & $0.70^{\text {ns }}$ \\
\hline $\begin{array}{l}\text { TBA }(\mathrm{nm}) \\
\text { Microbiological } \\
\text { parameters }\end{array}$ & $\begin{array}{c}0.128 \pm \\
0.00\end{array}$ & $\begin{array}{c}0.129 \pm \\
0.00\end{array}$ & $\begin{array}{c}0.130 \pm \\
0.00\end{array}$ & $\begin{array}{c}0.131 \pm \\
0.00\end{array}$ & $\begin{array}{c}0.131 \pm \\
0.00\end{array}$ & $\begin{array}{c}0.132 \pm \\
0.00\end{array}$ & $\begin{array}{c}0.133 \pm \\
0.00\end{array}$ & $0.003^{\text {ns }}$ \\
\hline SPC $\left(\log _{10} c f u / g\right)$ & $\begin{array}{c}3.10 \pm \\
0.10\end{array}$ & $\begin{array}{c}3.20 \pm \\
0.10\end{array}$ & $\begin{array}{c}3.26 \pm \\
0.14\end{array}$ & $\begin{array}{c}3.30 \pm \\
0.17\end{array}$ & $\begin{array}{c}3.36 \pm \\
0.06\end{array}$ & $\begin{array}{c}3.41 \pm \\
0.06\end{array}$ & $\begin{array}{c}3.52 \pm \\
0.04\end{array}$ & $0.37^{\mathrm{ns}}$ \\
\hline Coliform & nil & nil & nil & nil & nil & nil & nil & Nil \\
\hline
\end{tabular}

Figures are the average \pm standard error of three replications; ns - non-significant $(p>0.01)$ abc -mean with different superscripts within columns differ significantly $(p \leq 0.01)$ 
dried powder should be between 60-80 percent $^{3}$ while the formulated dietary supplement was having a dispersibility percent above 80 throughout the storage period, hence exhibited good reconstitution characteristic.

\section{Change in insolubility index}

Solubility is also an important phenomenon to find out proper recombining and completeness of dissolving of dried powder in water and to assess the extent of insoluble material. The insolubility index is a measure of water insoluble materials, which in turn measured the reconstitutability of the powder. The results with respect to change in insolubility index as a function of storage period is given in Table 2. It may be observed that the insolubility index ranged from 0.65 to $0.68 \mathrm{ml}$ during the storage period of 180 days. It can also be seen that there was slight increase in the insolubility index as the storage period progressed. However, non significant ( $p>0.01$ ) increase in insolubility index was observed during the storage period. It is evident from table 2 that insolubility index of spray dried dietary supplement lies within the maximum limit of $2 \mathrm{ml}$ as per specifications of Bureau of Indian standards for spray dried whole milk powder (IS: 1165, 1992). This corresponds to the solubility of 98.5 percent. Since, in none of the storage period the insolubility index exceeded this limit, thus it can be said that the formulation had good solubility behavior. The solubility index of milk powders is a function of storage time and temperature and also the level of moisture. Normally, beyond certain period of storage at elevated temperature the solubility index increases. Both casein and milk serum proteins are also involved in the insolubilisation. The protein carbohydrate interaction was reported to cause a decrease in solubility hence increase in the insolubility index ${ }^{33}$. Bouvier et $\mathrm{al}^{6}$ observed that the milk powders have limited shelf life as their solubility decreases during storage. Chudy et $\mathrm{al}^{9}$ analyzed whole milk powder stored for 6 months and noticed good solubility $\left(0.6 \mathrm{~cm}^{3}\right)$, but the solubility of egg and milk-egg powder decreased and their solubility index increased to $10.5 \mathrm{~cm}^{3}$ and $3.1 \mathrm{~cm}^{3}$, respectively. From the results it may be concluded that the dietary formulation had excellent reconstitution properties, which also lies within the prescribed standards.

\section{Change in Thiobarbituric acid (TBA) value}

Thiobarbituric acid value (TBA) when reacts with the resultant products of auto-oxidation give rises to yellow color in the medium. The extent of lipid oxidation in dietary supplement during storage was measured in terms of TBA value. It is an indirect method of ascertaining oxidative changes but can be correlated with other method. The results with respect to change in TBA value for dietary supplement as influenced by the storage period are presented in Table 2. The TBA value ranged from 0.128 to 0.133 . It may be observed that the TBA value of the dietary supplement increased from 0.128 to 0.133 during the storage period of 180 days. There was observed a gradually increase in the TBA value of the dietary supplement from 0.128 to 0.130 during the first 45 days thereafter it remained constant for the next 30 days $(0.131)$ followed by a slight increase from 0.131 to 0.133 during later part of storage period. However a non significant ( $p>0.01$ ) change was found in the TBA value of the dietary supplement over the period of storage. During storage the increase in the TBA could be due to the

Table 3: Changes in sensory scores of dietary supplement during storage

\begin{tabular}{lcccccccc}
\hline \multirow{2}{*}{$\begin{array}{l}\text { Sensory } \\
\text { Attributes }\end{array}$} & $\mathbf{0}$ & $\mathbf{3 0}$ & $\mathbf{4 5}$ & $\mathbf{6 0}$ & $\mathbf{9 0}$ & $\mathbf{1 2 0}$ & $\mathbf{1 8 0}$ & $\mathbf{C D}_{0.05}$ \\
\hline Color and & $7.64 \pm$ & $7.64 \pm$ & $7.60 \pm$ & $7.57 \pm$ & $7.43 \pm$ & $7.39 \pm$ & $7.14 \pm$ & $0.67^{\text {ns }}$ \\
appearance & 0.21 & 0.21 & 0.17 & 0.20 & 0.17 & 0.17 & 0.14 & \\
Flavor & $7.37 \pm$ & $7.26 \pm$ & $7.21 \pm$ & $7.21 \pm$ & $7.10 \pm$ & $7.03 \pm$ & $6.74 \pm$ & $0.60^{\text {ns }}$ \\
& 0.14 & 0.13 & 0.18 & 0.18 & 0.17 & 0.22 & 0.19 & \\
Overall & $7.51 \pm$ & $7.45 \pm$ & $7.41 \pm$ & $7.39 \pm$ & $7.26 \pm$ & $7.18 \pm$ & $7.00 \pm$ & $0.48^{\text {ns }}$ \\
acceptability & 0.13 & 0.12 & 0.13 & 0.18 & 0.15 & 0.14 & 0.11 & \\
\hline
\end{tabular}

Figures are the average \pm standard error of three replications; $n s-$ non-significant $(p>0.01)$ 
oxidation of free fat which is preceded by oxidation of sulphydryl group of compounds ${ }^{13}$.The left over oxygen shows a secondary effect by interacting with lipids which causes auto-oxidation of unsaturated fatty acids ${ }^{29}$. The reaction involves free radicals and is catalyzed by traces of metals. Once the free radicals have been formed an auto catalytic reaction sets in, with the reaction products catalyzing the reaction so that its rate increases with time ${ }^{36}$. This results in formation of many carbonyl compounds. Several studies have shown the TBA value to increase with storage period. Jha et $\mathrm{al}^{21}$ found an increase in TBA value from initial 0.01 to 0.11 after 24 weeks storage at $30{ }^{\circ} \mathrm{C}$ in instant kheer mix. An increase in the TBA value from 0.01 to 0.092 was also reported by Arora, ${ }^{4}$ after 3 months of storage of instant dalia mix powder. Bunkar et $\mathrm{al}^{7}$. also observed an increase in TBA value from 0.067 to 0.613 in pearl millet based kheer mix during 180 days of storage period. In the present investigation, also an increase in the TBA value was found however, the extent of increase in TBA value was within the acceptable limits.

\section{Change in Free fatty acid (FFA) value}

Free fatty acid (FFA) is a measure of extent of lipid hydrolysis. Ester linkages of lipid are subjected to hydrolysis resulting from the thermal stress or chemical actions due to which FFA are formed in the system. An increased amount of FFA signifies an increased amount of hydrolysis of lipids. The results pertaining to change in the FFA as a function of storage conditions are given in Table 2. It may be observed that the FFA value of the dietary supplement increased from 2.87 to 3.80 $\mathrm{meq} / \mathrm{g}$ during 180 days. There has been a consistent increase in the FFA value as the storage period progressed. However, table 2 indicates that, there was non-significant $(p>0.01)$ change observed in the FFA values of the supplement during storage periods from 0 to 180 days. Such an increase in the FFA content could be attributed to a possible breakdown of lipids in the product. The formulation was also found to have vegetable oil as a source of fat which has more tendencies towards oxidation due to the presence of unsaturated fatty acids that could have been the reason for the increase in the FFA content of the formulation. Bacterial lipases also affect the FFA content of dairy and food products and the increase in FFA content often correlates well with time and temperature of storage. Chen et $\mathrm{al}^{8}$. reported that after storage for 2 weeks at 37 ${ }^{\circ} \mathrm{C}$, the levels of short-chain FFAs in the powders exceeded the sensory threshold values in the reconstituted whole milk powder at $125 \mathrm{~g} \mathrm{~L}^{-}{ }^{1}$. Chen et $\mathrm{al}^{8}$ have also revealed that the increase in the levels of total FFA content in whole milk powders containing thermostable lipases increased during storage at $37^{\circ} \mathrm{C}$. Marathe et al. ${ }^{24}$ also reported an increase in free fatty acids content from 22 to 44 percent during 3 months storage and 55 percent during 6 months storage of wheat flour. Gupta and $\mathrm{RaO}^{15}$ also noticed an increase in the free fatty acid (FFA) content of raw jatropha oil with storage time of 150 days. Our results therefore, corroborate with the observations reported by earlier researchers. Thus, it can be concluded that an increase in the FFA was observed during the storage. However, it was not affecting the sensory acceptability as well as was found to be within the permissible limits.

\section{Changes in sensory profile of dietary supplement during storage}

Sensory evaluation was one of the earliest methods of quality control and it is still widely used in industry. From the consumer's point of view, it is one of the primary characteristics based on which the quality of the product is decided. The stored samples of the dietary supplement were subjected to the sensory evaluation to ensure the color and appearance, flavor, consistency and overall acceptability on the 9 point hedonic scale. The samples were evaluated on the sensory basis at monthly interval. The results pertaining to sensory evaluation of the dietary supplement is mentioned in table 3. It may be seen from the table that sensory scores for attributes such as color and appearance, flavor and overall acceptability of dried dietary supplement declined with the progress of the storage. After 180 days of storage the color and appearance score declined from the initial 7.64 to 7.14 . The flavor score decreased from 7.37 to 6.74. Decrease was also observed in the overall acceptability score as it dropped from 7.51 to 7.00 during the storage period. The statistical analysis of sensory responses for the dietary supplement depicts that there was a non significant $(p>0.01)$ difference observed in the color and appearance score of dried dietary supplement. It is also evident from the table that there was a non significant ( $p>0.01$ ) change observed in all sensory attributes of the dried dietary supplement during a 
storage period of 180 days. The sensory scores were found to be more than 7 on 9 point hedonic scale. It was therefore concluded that the dietary supplement has presented an acceptable score even during 180 days of storage.

\section{Changes in microbiological quality of dietary supplement during storage}

One of the major factors affecting food deterioration during storage is the growth and activities of micro-organisms principally the bacteria. Manifestation of growth of microorganisms depends upon the physico-chemical characteristics of food product, moisture content, $\mathrm{pH}$, temperature of storage etc. During storage period the samples of the dietary supplement were also subjected to assess changes in their microbiological quality in terms of standard plate count and the coliform count.

\section{Effect on standard plate count}

It may be observed that the SPC values ranged from 3.10 to 3.52 . The results presented in table 2 shows that though the SPC increased gradually during storage. However, this increase was non-significant $(p>0.01)$ over a period of 180 days of storage. On similar terms, Paul ${ }^{30}$ reported no significant change in the standard plate count of the low lactose infant formula during the storage period of 6 months. While, the findings of the present investigation are quite contrary to the work reported by Khamrui ${ }^{22}$ who has found a decreasing trend in the SPC in dried whey based fruit juice mix powder during storage period of 6 months.

\section{Effect on coliform count}

Coliform in any diary product indicates the hygienic condition maintained during production and packaging. In the present investigation coliform were found to be absent in all the samples throughout the storage period. Even on the zero day of storage the samples of dietary supplement showed nil coliform count. This indicates that proper hygienic precautions had been taken during production and packaging of dietary supplement. It is evident from the results that dietary supplement being a dried product was not found suitable for the multiplication of the bacteria. On the basis of the above results, it may be concluded that the stored samples of the dietary supplement conformed to the Indian Standards (IS: 1165,1967$)$ with regard to SPC not more than 50,000 per $\mathrm{g}$ and coliform counts (nil); the dietary supplement was therefore found to be of good microbiological quality.

\section{CONCLUSION}

The optimum level of fat, protein and carbohydrate in dietary supplement with validated means of response as 4.37 percent moisture, 66.15 percent carbohydrate, 15.93 percent protein, 10.15 percent fat and 3.39 percent ash was $10 \mathrm{~g}, 27.2 \mathrm{~g}$ and $62 \mathrm{~g}$ respectively. The dietary formulation supplied a total of $417 \mathrm{kcal}$ energy per $100 \mathrm{~g}$. Furthermore dietary supplement could be stored for a period of six months without appreciable changes in its physicochemical and sensory characteristics.

\section{Acknowledgements}

We gratefully acknowledge the assistance and support provided by the Director, ICAR-National Dairy Research Institute, Karnal for carrying out the research work.

\section{REFERENCES}

1. ADMI. 1965. Standards for grades of dry milk, including methods of analysis. Bulletin 915 (Revised). American Dry Milk Institute, Chicago, USA.

2. AOAC. 1995. Official Methods of Analysis of AOAC International. Vol.11, $16^{\text {th }}$ edn, Virginia, USA.

3. APV. 1989. Dryer handbook (DRH-889). APV Crepaco Inc. Rosemont, IL.
4. Arora, A. 2006. Shelf life evaluation of instant dalia mix powder. M.Sc. thesis. NDRI (Deemed University) Karnal, India.

5. Bodyfelt , F.W., Tobias, J. and Trout, G.M. 1988. The sensory evaluation of the dairy products. AVI Publ Co, New York.

6. Bouvier, J.M., Collado, M., Gardiner, D., Scott, M. and Schuck, P. 2013. Physical and rehydration properties of milk protein 
concentrates: comparison of spray-dried and extrusion porosified powders. Dairy Science and Technology. 93:387-399

7. Bunkar DS, Jha A, Mahajan A and Unnikrishnan VS (2014). Kinetics of changes in shelf life parameters during storage of pearl millet based kheer mix and development of a shelf life prediction model. Journal of Food Science and Technology. 51(12):3740-3748

8. Chen, L., Daniel, R.M. and Coolbear, T. 2003. Detection and impact of protease and lipase activities in milk and milk powders. International Dairy Journal, 13: 255-275.

9. Chudy, S., Pikul, J., Rudziñska, M. and Makowska, A. 2015. The effect of storage on physicochemical properties of spraydried milk, egg and milk-egg mixture. Acta Agrophysica. 22(1): 17-26

10. Cristina SA, Sevastipa M, Ancupa RM, Ramona S and Tofanã M. (2012). Influence of the storage conditions on physicochemical parameters of infant formula. Journal of Agroalimentary Processes and Technologies.18(1): 61-64

11. Deeth, H.C. and Fitz-Gerald, C.H. 1976. Lipolysis in dairy products- A review. Australian Journal of Dairy Technology, 31: 53-64.

12. Fitzpatrick JJ, Barry K, Cerqueira, PSM, Iqbal T, Neill'O J and Roose YH. (2007). Effect of composition and storage conditions on the flowability of dairy powders. Indian Dairy Journal.17:383-392

13. Flink, J.M. and Kessler, H.G. 1986. Reaction kinetics evaluation of the oxidative changes in stored UHT milk. Miilchwissenschaft, 41(2): 9094.

14. Guariguata L, Whiting DR, Hambleton I, Beagley J, Linnenkamp U, and Shaw, J.E. 2014. Global estimates of diabetes prevalence for 2013 and projections for 2035. Diabetes Res Clin Pract 103: 137-149.

15. Gupta, R.C. and Rao, D.G. 2008. Effect of storage time on yield and free fatty acid (FFA) content of raw jatropha oil. XXXII National Systems Conference, NSC 2008, December 17-19, 440-443.

16. Hall, C.W. and Hedrick, T.I. 1971. Drying of milk and milk products. Westport, Conneeticut, USA. AVI Publ. Co.

17. Haughty, G.A., Maturin, L.J. and Koening,
E.K. 1993. Microbiological count methods. In Marshall, R.T. (Ed.), Standard methods for the examination of dairy products $\left(16^{\text {th }} \mathrm{ed}\right.$.) American Public Health Association, 213244.

18. ICMR. 2005. Guidelines for management of Type 2 Diabetes. World Health Organization Workshop, Indian Council of Medical Research, 2-4 May, 2003.

19. IS: SP: 18-Part XI. 1981. Indian Standards. Handbook of food analysis. Indian Standard Institution, Manak Bhavan, New Delhi.

20. Jha A, Patel AA, Singh RRB (2002) Physicochemical properties of instant kheer mix. Lait 82:501-513

21. Jha, A. 2000. Development of process for long life kheer and instant kheer mix. Ph.D Thesis. NDRI. Karnal, Haryana.

22. Khamrui K. 2000. Development of technology for concentrated and dried whey based fruit juice mixes. Ph.D Thesis. NDRI. Karnal, Haryana.

23. Kuznetsov, V.P. 1979. Study of the characteristics of rapid solubility of dried milk during storage. Cited: DSA. 44:3233.

24. Marathe, S. A., Machaiah, J. P., Rao, B. Y. K., Pednekar, M. D. and Sudha Rao, V. 2002. Extension of shelf-life of whole-wheat flour by gamma radiation. International Journal of Food Science and Technology, 37: 163-168.

25. Marshall, R.T. 1993. Standard Methods for the Examination of Dairy Products. American Public Health Association, Washington, 546.

26. Mimouni, A., Deeth, H.C., Whittaker, A.K., Gidley, M. J. and Bhandari, B.R. 2010. Rehydration of high-protein-containing dairy powder: Slow- and fast-dissolving components and storage effects. Dairy Science Technology. 90:335-344

27. Mirmiran, P., Bahadoran, Z. and Azizi, F. 2014. Functional foods-based diet as a novel dietary approach for management of type 2 diabetes and its complications: A review. World Journal of Diabetes. 2014 Jun 15; 5(3): 267-281.

28. Mrithyunjaya, N. and Bhanumurthi, J.L. 1987. Shelf life of laminate and tin packed whole milk powder. Indian Journal of Dairy Science, 40,78 . 
29. Park, O.W. 1972. Carbonyl compounds associated with the off flavour in spontaneously oxidized milk. Journal of Dairy Science, 46(4): 295-301.

30. Paul, S.C. 1984. Technological aspects of manufacturing low lactose infant formula. Ph.D Thesis. Kurukshetra University, Kurukshetra.

31. Pawar, K. and Thompkinson, D.K. 2014. Optimisation of ingredients for formulating a diabetic dietary supplement. Journal of Food Science and Technology, 51(5): 875-883. doi: 10.1007/s13197-011-0566-y

32. Scheidegger, D., Radici, P.M., Vergara-Roig., V.A., Bosio, N.S., Pesce, S.F., Pecora, R.P., Romano, J.C.P. and Kivatinitz, S.C. 2013. Evaluation of Milk Powder Quality by Protein Oxidative Modifications. Journal of Dairy Science. 96(6):3414-3423.

33. Sharma, A., Jana, A.H. and Chavan, R.S. 2012. Functionality of Milk Powders and Milk-
Based Powders for End Use Applications-A Review. Comprehensive reviews in food science and food safety.11: 518-528

34. Sharma, R.S. 1989. Physico-chemical changes in milk powders during storage. A compendium of lectures delivered at refresher course on drying of milk and milk products. Gujarat Agricultural University, Anand Gujarat.

35. Strange ED, Beneddict, R.C., Smith, J.L. and Swiff, C.E. 1977. Evaluation of rapid test for monitoring alterations in meat quality during storage. Journal of Food Protection, 40: 843847.

36. Williams, J.C. 1976. Chemical and nonenzymatic changes in intermediate moisture foods. In: Intermediate Moisture Foods. Ed. by Davies, R., Birch, G.G. and Parker, K.J., Applied Sci. Publishers, London, UK, 100119. 